\title{
Responses of native broadleaved woody species to elevated ozone in subtropical China
}

\author{
Weiwei Zhang ${ }^{\mathrm{a}, \mathrm{b}}$, Zhaozhong Feng ${ }^{\mathrm{a}, *, 1}$, Xiaoke Wang ${ }^{\mathrm{a}, *}$, Junfeng Niu ${ }^{\mathrm{a}}$ \\ ${ }^{a}$ State Key Laboratory of Urban and Regional Ecology, Research Center for Eco-Environmental Sciences, Chinese Academy of Sciences, 2871 Mailbox, Shuangqing Road 18, \\ Haidian District, Beijing 100085, China \\ ${ }^{\mathrm{b}}$ Key Laboratory of Black Soil Ecology, Northeast Institute of Geography and Agroecology, Chinese Academy of Sciences, Harbin 150081, China
}

\section{A R T I C L E I N F O}

\section{Article history:}

Received 12 August 2011

Received in revised form 10 December 2011

Accepted 15 December 2011

\section{Keywords:}

Ozone

Subtropical species

Sensitivity

Visible symptom

Gas exchange

Antioxidant defense

\begin{abstract}
A B S T R A C T
To assess ozone sensitivity of subtropical broadleaved tree species and explore possible underlying mechanisms, six evergreen and two deciduous native species were exposed to either charcoal-filtered air or elevated $\mathrm{O}_{3}\left(\mathrm{E}-\mathrm{O}_{3}, \sim 150 \mathrm{ppb}\right)$ for one growing season. Initial visible symptoms in deciduous species appeared much earlier than those in evergreen species. The species which first showed visible symptoms also had the largest reductions in biomass. $\mathrm{E}-\mathrm{O}_{3}$ induced significant decreases in photosynthesis rate, chlorophyll content and antioxidant capacity but a significant increase in malondialdehyde content in two deciduous species and two evergreen species (Cinnamomum camphora and Cyclobalanopsis glauca). Except $C$. glauca, however, $\mathrm{E}^{-\mathrm{O}_{3}}$ had no significant effects on stomatal conductance $\left(\mathrm{g}_{\mathrm{s}}\right)$, total phenols and ascorbate contents. Difference in $\mathrm{O}_{3}$ sensitivity among all species was strongly attributed to specific leaf mass rather than $g_{s}$. It suggests that some subtropical tree species will be threatened by rising $\mathrm{O}_{3}$ concentrations in the near future.
\end{abstract}

(c) 2011 Elsevier Ltd. All rights reserved.

\section{Introduction}

Tropospheric ozone $\left(\mathrm{O}_{3}\right)$ is considered as one of the most critical air pollutants for forests (Paoletti et al., 2010) due to its detrimental effects on carbon sequestration (Augustaitis and Bytnerowicz, 2008; McLaughlin et al., 2007), forest health (Paoletti, 2009; Tkacz et al., 2008) and biodiversity (Matyssek et al., 2010; Pretzsch et al., 2010). A recent quantitative meta-analysis found that current ambient $\left[\mathrm{O}_{3}\right]$ (40 ppb, on average) and elevated $\left[\mathrm{O}_{3}\right](97 \mathrm{ppb})$ significantly reduced the total biomass of trees by $7 \%$ and $17 \%$ compared with those grown in charcoal-filtered controls, respectively (Wittig et al., 2009). Furthermore, $\mathrm{O}_{3}$ induced a variety of physiological and biochemical alterations at the leaf level, including reduction in photosynthesis, stomata closure, chlorophyll degradation, and premature senescence, with or without visible foliar injury (Matyssek et al., 2007; Pina and Moraes, 2010; Tausz et al., 2007).

On the other hand, tree species can actively defend against $\mathrm{O}_{3}$ through two main pathways. One is the avoidance strategy, i.e. the ability of leaves to partially close stoma to exclude $\mathrm{O}_{3}$ from leaf

\footnotetext{
* Corresponding authors.

E-mail addresses: zhzhfeng201@hotmail.com, fzz@rcees.ac.cn (Z. Feng), wangxk@rcees.ac.cn (X. Wang).

1 Present address: Department of Plant and Environmental Sciences, University of Gothenburg, Göteborg SE-405 30, Sweden.
}

intercellular space (Kitao et al., 2009; Paoletti et al. 2009); the other is the repair strategy, i.e. the capacity to activate detoxifying systems (Castagna and Ranieri, 2009), especially cellular phenolic compounds and apoplastic ascorbate (AsA) although the relationship between the $\mathrm{O}_{3}$ sensitivity of a plant and its apoplastic AsA concentration remains controversial (D'Haese et al., 2005; Di Baccio et al., 2008). Many Mediterranean evergreen species were tolerant to high $\mathrm{O}_{3}$ levels in the summertime, due partly to their low stomatal conductance $\left(g_{s}\right)$ (Paoletti, 2006). However, Phillyrea latifolia was the most tolerant to $\mathrm{O}_{3}$ among three species due to higher antioxidant level despite having the highest $\mathrm{g}_{\mathrm{s}}$ (Nali et al., 2004). Di Baccio et al. (2008) compared two poplar clones with different sensitivity to $\mathrm{O}_{3}$ and found that $\mathrm{O}_{3}$-induced increase in antioxidant level in the sensitive poplar clone is not sufficient to counteract the oxidative stress due to its larger $g_{s}$. Hence, it can be inferred that the balance between $\mathrm{O}_{3}$ uptake and cellular antioxidant potential is very important in determining the sensitivity of plants to $\mathrm{O}_{3}$.

The negative impact of $\mathrm{O}_{3}$ on woody species has been well documented in the North America and Europe for their locally important trees like Pinus halepensis (e.g. Inclán et al., 2011), Populus tremuloides (e.g. McGrath et al., 2010), hybrid poplar (Populus maximowizii $\times$ trichocarpa) (e.g. Orendovici-Best et al., 2008), Betula pendula (Kontunen-Soppela et al., 2010; Oksanen et al., 2005), Fagus sylvatica (Gerosa et al., 2008; Haberer et al., 2007) and Quercus ilex 
(e.g. Calatayud et al., 2011). However, very little is known about effect of $\mathrm{O}_{3}$ on forests in Asia (Bytnerowicz et al., 2007; Yamaguchi et al., 2007). In China, only a few species have been investigated in elevated ozone, such as Ginkgo biloba (He et al., 2007), Quercus mongolica (Yan et al., 2010), Cinnamomum camphora (Feng et al., 2011), Liriodendron chinense (Zhang et al., 2011) and Metasequoia glyptostroboides (Feng et al., 2008). Furthermore, among all investigated species, most were the boreal and temperate tree species and there were also a few Mediterranean evergreen tree species. However, as one of the most important types of vegetations flora, evergreen/deciduous broadleaved species in subtropical terrestrial ecosystem have been rarely investigated.

Due to subtropical climate features and large amounts of $\mathrm{NO}_{x}$ and VOC emissions (main precursors to $\mathrm{O}_{3}$ formation), the ambient $\mathrm{O}_{3}$ in eastern China has reached such a high level that induced significant yield loss in food crops (Wang et al., 2007). Based on the China forest dataset of 1961-2005, a recent model has indicated that ambient $\mathrm{O}_{3}$ induced a much greater loss of net carbon storage in (sub)-tropical broadleaf evergreen (9.6\%) and deciduous (43.1\%) forests than that in temperate broadleaf evergreen (7.6\%) and deciduous (21.1\%) forest, respectively (Ren et al., 2011). Therefore, it is imperative to investigate the response of subtropical broadleaved species to $\mathrm{O}_{3}$ through field observation in order to protect biodiversity and enhance carbon sequestration in the subtropical forest ecosystem.

In this study, eight native broadleaved woody species, including six evergreen and two deciduous tree species, were exposed to relatively high $\mathrm{O}_{3}$ concentration $(\sim 150 \mathrm{ppb})$ under local subtropical climate conditions. The objectives were (1) to compare the $\mathrm{O}_{3}$ sensitivity among the tested woody species based on the AOT40 value at initial visible injury and their growth response; (2) to explore the possible mechanisms on differential response to $\mathrm{O}_{3}$ among species in terms of foliar traits, $g_{s}$, antioxidant capacity and the combination of these parameters.

\section{Materials and methods}

\subsection{Experimental site}

The experimental site was located at the Tiantong National Field Observation and Research Station for Subtropical Forest Ecosystems $\left(29^{\circ} 48^{\prime} \mathrm{N}, 121^{\circ} 47^{\prime} \mathrm{E}\right)$, Ningbo, Zhejiang province, China. The site is typical of the humid subtropical monsoon climate with cold dry winters and warm wet summers. The annual mean temperature is $16.2{ }^{\circ} \mathrm{C}$ and the warmest month is July with a mean temperature of $28.1^{\circ} \mathrm{C}$. Average annual precipitation is $1375 \mathrm{~mm}$, concentrated from June to August.

\subsection{Ozone fumigation}

$\mathrm{O}_{3}$ was generated from pure oxygen by an electrical discharge $\mathrm{O}_{3}$ generator (HY003, Chuangcheng Co. Jinan, China) and then mixed with charcoal-filtered ambient air (CF) to achieve the target $\mathrm{O}_{3}$ concentration in three open-top chambers (OTCs, octagonal base, $7 \mathrm{~m}^{2}$ of growth space and $2.6 \mathrm{~m}$ in height). The averaged air velocity in the chambers corresponded to approximately two complete air changes per minute. The concentration of $\mathrm{O}_{3}$ in the OTCs was continuously monitored at approximately $10 \mathrm{~cm}$ above plant canopy using a $\mathrm{UV}$ absorption $\mathrm{O}_{3}$ analyzer (Model 49i-Thermo, USA).

In this study, there were two treatments: $\mathrm{CF}$ and elevated $\mathrm{O}_{3}\left(\sim 150 \mathrm{ppb}, \mathrm{E}-\mathrm{O}_{3}\right)$ with three chambers replicates, respectively. $\mathrm{O}_{3}$ fumigation started from 6 July 2008 and lasted to 28 September with a daily maximum of $8 \mathrm{~h}$ (from 08:00 to 16:00) when there was no rain, fog, mist or dew. There were in total 47 effective days during the experiment because of the interruptions in rainy and cloudy days, including three typhoons (from 21 August to 26 August, from 31 August to 7 September and from 9 September to 17 September). The cumulative $\mathrm{O}_{3}$ exposure over a threshold of the 1-h average $\left[\mathrm{O}_{3}\right]$ of $40 \mathrm{ppb}$ (AOT40) was $38.24 \mathrm{ppm} \mathrm{h}$ in $\mathrm{E}-\mathrm{O}_{3}$ by the end of the experiment.

\subsection{Plant materials}

Eight native broadleaved species were selected considering their dominance in subtropical forest or their potential for urban greening in eastern China. The characteristics of these tree species are described in Table 1 . There were two deciduous
Table 1

The characteristics of eight native broadleaved woody species in subtropical China.

\begin{tabular}{|c|c|c|c|}
\hline Scientific name & Family & Life type & Functional leaf trait \\
\hline $\begin{array}{l}\text { Liriodendron } \\
\text { chinense }\end{array}$ & Magnoliceae & Deciduous tree & Green, thin and soft \\
\hline $\begin{array}{l}\text { Liquidambar } \\
\text { formosana }\end{array}$ & Hamalidaceae & Deciduous tree & $\begin{array}{l}\text { Green and thinly } \\
\text { leathery }\end{array}$ \\
\hline Ilex integra & Aquifoliaceae & Evergreen shrub & $\begin{array}{l}\text { Dark green, glossy } \\
\text { leathery, stiff and thick }\end{array}$ \\
\hline Photinia $\times$ fraseri & Rosaceae & Evergreen shrub & $\begin{array}{l}\text { Dark green, glossy } \\
\text { leathery, stiff and thick }\end{array}$ \\
\hline $\begin{array}{l}\text { Cinnamomum } \\
\text { camphora }\end{array}$ & Lauraceae & Evergreen tree & $\begin{array}{l}\text { Dark green and glossy } \\
\text { leathery }\end{array}$ \\
\hline $\begin{array}{l}\text { Cyclobalanopsis } \\
\text { glauca }\end{array}$ & Fagaceae & Evergreen tree & $\begin{array}{l}\text { Dark green, glossy } \\
\text { leathery and stiff }\end{array}$ \\
\hline Neolitsea sericea & Lauraceae & Evergreen tree & $\begin{array}{l}\text { Green, glossy leathery, } \\
\text { and golden densely fine } \\
\text { hairy on both surfaces } \\
\text { of expanding leaf }\end{array}$ \\
\hline Schima superba & Theaceae & Evergreen tree & $\begin{array}{l}\text { Dark green and glossy } \\
\text { leathery }\end{array}$ \\
\hline
\end{tabular}

(L. chinense and Liquidambar formosana) and six evergreen species (C. camphora Cyclobalanopsis glauca, Schima superb, Ilex integra, Photinia $\times$ fraseri and Neolitsed sericea).

At December 2007, six-month-old seedlings of the selected species were individually planted into $6 \mathrm{~L}$ circular plastic pots in a temperature controlled and double glazed greenhouse $\left(25 \pm 2{ }^{\circ} \mathrm{C}\right.$, air relative humility $\left.70-90 \%\right)$. Pots were filled with native yellowish brown lateritic soil (soil organic C $0.98 \%$, total $\mathrm{N} 1.36 \mathrm{~g} \mathrm{~kg}^{-1}$, total $\mathrm{P}$ $0.27 \mathrm{~g} \mathrm{~kg}^{-1}$, total $\mathrm{K} 1.41 \%$ ) in mixture with litter collected under firry forest at the ratio of $1: 1(\mathrm{v} / \mathrm{v})$. After 4 months' cultivation, these seedlings were moved outside for field acclimation and then grew in OTCs for one month. Twenty four seedlings with similar height and basal diameter were selected for each species (with 10-20 fully expanded leaves) and randomly assigned to six chambers with four plants per OTC before $\mathrm{O}_{3}$ fumigation started. The growth status (stem height and basal diameter) in each species did not show any significant difference between $\mathrm{CF}$ and $\mathrm{E}-\mathrm{O}_{3}$ suggesting that the original difference of seedlings between treatments can be neglected for each species.

The position of plants was changed every 3-5 days within each OTC to eliminate positional effects. During the growth of seedlings, average air temperature, average relative air humidity and total radiation density were $25.6^{\circ} \mathrm{C}, 90 \%$ and $13.8 \mathrm{MJ} \mathrm{m}^{-2} \mathrm{~d}^{-1}$ respectively. Plants were well watered with tap water to avoid drought stress.

\subsection{Sampling, physiological and biochemical measurements}

For each seedling, stem height and stem basal diameter in two directions at $5 \mathrm{~cm}$ of stem height were measured at the beginning of the experiment. At the end of the experiment, the upper fully expanded leaves (3rd to 7th leaf position from the apex) were used for gas exchange measurement and biochemical analysis. Finally, all plants were harvested and separated into leaves, stems and roots. Dry mass was determined after oven-drying at $80^{\circ} \mathrm{C}$ until a constant weight.

\subsubsection{Visible $\mathrm{O}_{3}$ injury}

Current-year leaves of each seedling were observed every two days until symptoms first appeared and they were checked twice a week thereafter. The date of first foliar injury onset was defined as plants showed the same symptoms in three replicated chambers. Visible foliar injury as well as its onset date was recorded, and the AOT40 at initial visible injury onset (AOT40_injury) was calculated as well.

\subsubsection{Gas exchange measurement}

Two fully expanded upper leaves per seedling and three different plants per chamber were randomly selected. Gas exchange was measured with a portable photosynthesis system fitted with a 6400-40 leaf chamber fluorometer (LCF) (LI6400, LI-COR Inc. Lincoln, NE, USA). The system controlled saturating PPDF at $1000 \mu \mathrm{mol} \mathrm{m}^{-2} \mathrm{~s}^{-1}$, block temperature at $27 \pm 0.5{ }^{\circ} \mathrm{C}, \mathrm{CO}_{2}$ at $380 \mathrm{ppm}$ with a supply from pure $\mathrm{CO}_{2}$ cylinder, and relative humidity $(\mathrm{RH})$ at $50 \%-65 \%$. All measurements were conducted during 09:00-14:00 h, after which the leaves for gas exchange and one additional leaf were punched for sampling, avoiding the mid-vein. Leaf discs $\left(\sim 0.8 \mathrm{~cm}^{2}\right)$ were plunged immediately into liquid $\mathrm{N}$ and then stored in $-80^{\circ} \mathrm{C}$ for physiological and biochemical analysis. Of all, 8 leaf discs in each plant were ovendried for $48 \mathrm{~h}$ at $80^{\circ} \mathrm{C}$ to calculate specific leaf mass (SLM) as dry mass per unit of leaf area.

\subsubsection{Leaf chlorophyll content}

Two leaf discs per plant from three plants in each chamber were extracted with $4 \mathrm{ml} 95 \%$ ethanol in the dark for $48 \mathrm{~h}$ at $4{ }^{\circ} \mathrm{C}$. The absorbance of lea 
pigment extracts was measured at 646 and $663 \mathrm{~nm}$. Chlorophyll content was calculated according to the specific absorption coefficients provided by Lichtenthaler (1987)

\subsubsection{Malondialdehyde (MDA) and ascorbate (AsA) content}

Three leaf discs per plant $(\sim 80 \mathrm{mg})$ were homogenized in a pre-chilled mortar and extracted in $2 \mathrm{ml}$ ice-cold $6 \%(\mathrm{w} / \mathrm{v})$ trichloroacetic acid, and then centrifuged at $4000 \mathrm{rpm}$ for $10 \mathrm{~min}$. The absorbance was read at $450 \mathrm{~nm}$ in addition to 532 and $600 \mathrm{~nm}$, and MDA content was calculated using its extinction coefficient $155 \mathrm{mM}^{-1} \mathrm{~cm}^{-1}$ (Heath and Packer, 1968). The total ascorbate (AsA) content was determined following the protocol of Gillespie and Ainsworth (2007)

\subsubsection{Total antioxidant capacity (TAC) and total phenol content}

Samples ( $\sim 30 \mathrm{mg}$ ) were added to $2 \mathrm{ml}$ cold $70 \%(\mathrm{v} / \mathrm{v})$ ethanol and homogenized in darkness. The mixture was incubated for $20 \mathrm{~min}$ in darkness at $4{ }^{\circ} \mathrm{C}$, then centrifuged at $3000 \mathrm{rpm}$ for $20 \mathrm{~min}$. $100 \mu \mathrm{L}$ supernatant were taken for the ferric reducing antioxidant power (FRAP) assay to express the total antioxidant activity. The principle of the assay was conducted following the method of Benzie and Strain (1999), expressed as $\mathrm{Fe}^{3+}$ equivalents ( $\mu \mathrm{mol} \mathrm{Fe} \mathrm{F}^{2+} / \mathrm{g}$ fresh mass).

The rest of supernatant was shaken and incubated at $4{ }^{\circ} \mathrm{C}$ for $12 \mathrm{~h}$ in darkness. After the incubation, the mixture was centrifuged at $10,000 \mathrm{~g}$ for $20 \mathrm{~min}$ in darkness. The supernatant was analyzed for the total phenols content according to Kähkönen et al. (1999) as estimated by the Folin-Ciocalteau reagent, expressed as mg of Gallic acid equivalents (GAE) per unit of fresh mass.

\subsubsection{Potential available detoxification capacity}

The potential available detoxification capacity $(A)$ can be expressed as: $A=\mathrm{AA}_{\text {area }} / F_{\mathrm{O}_{3}}$, where $\mathrm{AA}_{\text {area }}$ is the area-based content of detoxification capacity or antioxidant content, and $\mathrm{F}_{\mathrm{O}_{3}}\left(\mathrm{nmol} \mathrm{m} \mathrm{n}^{-2} \mathrm{~s}^{-1}\right)$ is stomatal $\mathrm{O}_{3}$ flux. We calculated $\mathrm{AA}_{\text {area }}$ as: $\mathrm{AA}_{\mathrm{area}}=\mathrm{AA} \mathrm{A}_{\mathrm{dw}} \times \mathrm{SLM}$, where $\mathrm{AA}_{\mathrm{dw}}$ represents mass-based content of detoxification capacity or antioxidant measured above (Wieser et al., 2002). We calculated $F_{\mathrm{O}_{3}}$ as: $F_{\mathrm{O}_{3}}=\mathrm{O}_{\mathrm{a}}\left(g_{\mathrm{O}_{3}}\right)$, where $g_{\mathrm{O}_{3}}$ is $g_{\mathrm{s}}$ to water vapor multiplied by 0.613 and $O_{\mathrm{a}}$ is exposure $\mathrm{O}_{3}$ concentration (ppb) (Di Baccio et al., 2008).

\subsection{Statistical analysis}

In this study, the OTC was treated as an independent experimental unit for either treatment, which means that the mean of each chamber was obtained first from three to four replicated plants. The data for each variable was checked for normality and homogeneity of variance by Kolmogorov-Smirnov and Levenes' tests, respectively. The effects of $\mathrm{O}_{3}$, species and their interaction were tested with generalized linear model by using SPSS 16.0 software package for Windows. The difference of means between $\mathrm{CF}$ and $\mathrm{E}-\mathrm{O}_{3}$ was compared by Tukey's tests and considered significant at $P \leq 0.05$. Data shown in tables and figures were means $\pm \mathrm{SD}$ $(n=3)$. The relationship between the measured parameters was assessed by linear regression (SPSS 16.0) with a significant correlation when $P \leq 0.05$ and a tendency toward significance when $0.05<P<0.1$.

\section{Results}

\subsection{Visible injury}

At the end of the experiment, no visible $\mathrm{O}_{3}$ injury was found in any of eight species grown under $\mathrm{CF}$ conditions. However, typical visible symptoms were observed in $\mathrm{E}_{-} \mathrm{O}_{3}$, including foliar stipple, reddish stipple, necrotic spots, chlorotic mottling and brown spots (Table 2). L. chinense and L. formosana displayed visible symptoms on the upper surface of leaves when the AOT40 was about $10 \mathrm{ppm} \mathrm{h}$ (Table 2). Evergreen species C. camphora, C. glauca, S. superba and I. integra displayed symptoms when the AOT40 was higher than $20 \mathrm{ppm}$ h (Table 2). Also, symptoms developed with the increase in AOT40, and injuries in evergreen species were far less severe than those in two deciduous species along with leaf premature leaf senescence and severe defoliation at the end of the experiment. However, Photinia $\times$ fraseri and $N$. sericea did not display visible symptoms on current-year leaves. Table 2 shows the specific symptoms and the AOT40_injury for each species.

\subsection{Dry matter accumulation}

Across all species, $\mathrm{E}^{-} \mathrm{O}_{3}$ significantly decreased shoot mass, root mass, total biomass and SLM by $8 \%, 10 \%, 11 \%$ and $6 \%$, respectively (Table 3). Significant $\mathrm{O}_{3} \times$ species interactions were also observed in these variables $(P<0.001)$. In the $\mathrm{E}_{-} \mathrm{O}_{3}$ treatment, two deciduous species, $L$. chinense and $L$. formosana, showed significant reductions in shoot mass, root mass and total biomass (20\% 30\%), whereas evergreen species showed a decrease in biomass of less than $15 \%$ (Table 3). SLM of L. formosana, C. camphora and S. superba in $\mathrm{E}_{-} \mathrm{O}_{3}$ were significantly decreased by $20 \%, 12 \%$ and $11 \%$, respectively, whereas no significant effects were observed in other species.

\subsection{Gas exchange and leaf pigment content}

There were significant differences in gas exchange parameters and total chlorophyll content among the eight species (Table 4). Across all species, E- $\mathrm{O}_{3}$ significantly decreased $A_{\text {sat }}$ by $24 \%$, increased $C_{\mathrm{i}}$ by $8 \%$ and reduced total chlorophyll content by $19 \%$, but

Table 2

AOT40 at the initial visible $\mathrm{O}_{3}$ symptom onset and the description of the visible symptoms in eight native species exposed to elevated ozone (E-O ${ }_{3}$.

\begin{tabular}{|c|c|c|c|}
\hline Species & $\begin{array}{l}\text { Symptom onset date } \\
\text { (days after fumigation) }\end{array}$ & $\begin{array}{l}\text { Ozone dose } \\
\text { (AOT40, ppm h) }\end{array}$ & Description of symptoms \\
\hline Liriodendron chinense & 13 & 9.40 & $\begin{array}{l}\text { Necrotic spots appeared at the edges of adaxial surface of fully expanded leaves, and } \\
\text { expanding leaves turned light-brown. With the increase in AOT40, the light-brown } \\
\text { coloration turned dark-brown and necrotic spots formed patches. Finally, } \\
\text { pre-senescence and earlier defoliation occurred in developed leaves. }\end{array}$ \\
\hline Liquidambar formosana & 19 & 13.52 & $\begin{array}{l}\text { Light-brown foliar stipple and necrotic spots interspersed on the adaxial surface of } \\
\text { fully developed leaves. Expanding leaves turned light-green and/or yellow. Light-brown } \\
\text { necrotic spots turned to dark-brown necrotic patch with AOT40 increasing. Finally, } \\
\text { early leaf senescence with pronounced leaf abscission occurred after reddening. }\end{array}$ \\
\hline Cinnamomum camphora & 29 & 20.06 & $\begin{array}{l}\text { Chlorosis firstly appeared in fully developed leaves and then leaves turned yellow } \\
\text { with pale white stipple widespread on the surface of both developed and expanding } \\
\text { leaves. Young leaves were small, yellow, thin and weak. }\end{array}$ \\
\hline Cyclobalanopsis glauca & 40 & 27.85 & $\begin{array}{l}\text { Chlorotic mottling, light-green and/or yellow coloration and water-logging spots } \\
\text { were widespread on the adaxial surface of both developed and expanding leaves. } \\
\text { Young leaves turned light-green or yellow. }\end{array}$ \\
\hline Schima superba & 42 & 29.35 & $\begin{array}{l}\text { Brown spots were interspersed among the abaxial surface of leaves in some } \\
\text { individuals with no symptoms on adaxial surface of developed leaves. Expanding } \\
\text { leaves turned yellow, thin and easy to curl as well. }\end{array}$ \\
\hline Ilex integra & 50 & 33.36 & $\begin{array}{l}\text { Chlorosis firstly appeared in the middle of adaxial surface of fully developed leaves } \\
\text { along with red-brown and/or dark-brown spots. Dark-brown spots formed necrotic } \\
\text { patches interspersed on the adaxial surface. }\end{array}$ \\
\hline Photinia $\times$ fraseri & 84 & 38.24 & $\begin{array}{l}\text { No visible symptoms occurred in developed leaves, but the expanding leaves } \\
\text { showed curling. }\end{array}$ \\
\hline Neolitsea sericea & 84 & 38.24 & No visible symptoms occurred in both developed and expanding leaves. \\
\hline
\end{tabular}


Table 3

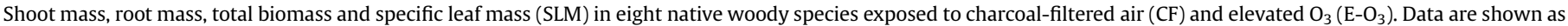

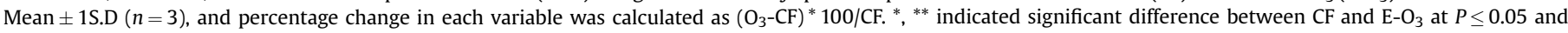
$P \leq 0.01$, respectively.

\begin{tabular}{|c|c|c|c|c|c|c|c|c|c|c|c|c|}
\hline & \multicolumn{3}{|c|}{ Shoot mass (g, DM) } & \multicolumn{3}{|c|}{ Root mass (g, DM) } & \multicolumn{3}{|c|}{ Total biomass (g, DM) } & \multicolumn{3}{|c|}{$\operatorname{SLM}\left(\mathrm{g}, \mathrm{DM} / \mathrm{m}^{2}\right)$} \\
\hline & $\mathrm{CF}$ & $\mathrm{E}-\mathrm{O}_{3}$ & $\%$ & $\mathrm{CF}$ & $\mathrm{E}-\mathrm{O}_{3}$ & $\%$ & $\mathrm{CF}$ & $\mathrm{E}-\mathrm{O}_{3}$ & $\%$ & $\mathrm{CF}$ & $\mathrm{E}-\mathrm{O}_{3}$ & $\%$ \\
\hline Liriodendron chinense & $43.5 \pm 3.01$ & $33.5 \pm 4.53$ & $-23^{*}$ & $26.1 \pm 3.02$ & $17.8 \pm 1.53$ & $-32^{*}$ & $69.5 \pm 4.51$ & $51.3 \pm 6.06$ & $-26^{*}$ & $33.0 \pm 2.04$ & $31.9 \pm 2.11$ & -4 \\
\hline Liquidambar formosana & $32.1 \pm 0.71$ & $26.1 \pm 1.67$ & $-19^{* *}$ & $19.1 \pm 1.79$ & $14.5 \pm 1.00$ & $-24^{*}$ & $52.2 \pm 2.79$ & $41.1 \pm 2.44$ & $-21^{* *}$ & $64.4 \pm 5.97$ & $51.6 \pm 1.75$ & $-20^{*}$ \\
\hline Cinnamomum camphora & $29.6 \pm 1.48$ & $29.0 \pm 3.56$ & -2 & $17.3 \pm 1.08$ & $16.3 \pm 1.07$ & -6 & $50.1 \pm 0.59$ & $43.8 \pm 1.60$ & $-13^{* *}$ & $77.2 \pm 1.31$ & $68.2 \pm 4.37$ & $-12^{*}$ \\
\hline Cyclobalanopsis glauca & $36.9 \pm 2.60$ & $36.0 \pm 2.81$ & -2 & $14.6 \pm 1.14$ & $13.2 \pm 1.11$ & -10 & $51.9 \pm 4.28$ & $48.5 \pm 2.36$ & -6 & $117.2 \pm 6.14$ & $115.4 \pm 3.24$ & -2 \\
\hline Schima superba & $43.9 \pm 2.71$ & $40.6 \pm 3.11$ & -7 & $20.0 \pm 3.85$ & $18.0 \pm 3.54$ & -10 & $65.3 \pm 2.39$ & $58.1 \pm 6.16$ & -11 & $89.2 \pm 3.49$ & $79.0 \pm 2.11$ & $-11^{*}$ \\
\hline Ilex integra & $47.7 \pm 2.81$ & $42.5 \pm 7.22$ & -11 & $20.7 \pm 1.22$ & $21.1 \pm 4.19$ & 2 & $68.4 \pm 3.43$ & $63.6 \pm 2.91$ & -7 & $141.8 \pm 1.85$ & $143.2 \pm 3.76$ & 1 \\
\hline Photinia $\times$ fraseri & $53.9 \pm 0.72$ & $51.0 \pm 2.82$ & -5 & $15.7 \pm 2.58$ & $16.6 \pm 3.23$ & 6 & $67.6 \pm 3.77$ & $65.9 \pm 3.31$ & -3 & $148.6 \pm 4.17$ & $155.6 \pm 7.95$ & 5 \\
\hline Neolitsea sericea & $27.6 \pm 1.29$ & $29.6 \pm 1.93$ & 7 & $15.7 \pm 1.18$ & $14.7 \pm 0.98$ & -7 & $44.0 \pm 0.70$ & $43.1 \pm 2.08$ & -2 & $117.1 \pm 2.67$ & $109.4 \pm 4.11$ & -7 \\
\hline Overall mean $(+\mid-)$ & & -8 & & & -10 & & & -11 & & & -6 & \\
\hline \multicolumn{13}{|l|}{ ANOVA (P-values) } \\
\hline $\mathrm{O}_{3}$ & & 0.001 & & & 0.003 & & & $<0.001$ & & & $<0.001$ & \\
\hline Species & & $<0.001$ & & & $<0.001$ & & & $<0.001$ & & & $<0.001$ & \\
\hline $\mathrm{O}_{3} *$ Species & & 0.032 & & & 0.040 & & & 0.003 & & & 0.001 & \\
\hline
\end{tabular}

had no significant effect on $g_{\mathrm{s}}$. E-O $\mathrm{O}_{3}$ induced larger decreases in $A_{\mathrm{sat}}$ (36\% 42\%) and total chlorophyll content (39\% 48\%) of two deciduous species in comparison with evergreen tree species although $C$. camphora and C. glauca also showed significant reduction in $A_{\text {sat }}$ and chlorophyll content.

\subsection{MDA, TAC and total antioxidant level}

Averaged across the eight species, $\mathrm{E}-\mathrm{O}_{3}$ significantly increased MDA content by $28 \%$ and decreased TAC by $13 \%$, but it had no effect on total phenols and total AsA level (Table 5). Significant increases in MDA by $\mathrm{E}^{-} \mathrm{O}_{3}$ were observed in both deciduous species $L$. chinense and $L$. formosana and some evergreen species (C. camphora, S. superba and Photinia $\times$ fraseri). Relative to $\mathrm{CF}, \mathrm{E}-\mathrm{O}_{3}$ significantly decreased TAC in deciduous species $L$. chinense and $L$. formosana by $33 \%$ and $28 \%$, respectively, whereas TAC increased in C. glauca by $32 \%$. $\mathrm{E}-\mathrm{O}_{3}$ had no significant effects on the total phenols level of any species and total AsA level with the exception of a significant increase in S. superba.

\subsection{Potential antioxidant availability and amount of antioxidants per unit of stomatal $\mathrm{O}_{3}$ flux}

Significant differences among species were observed in potential antioxidant capacity $\left(A_{\mathrm{TAC}}\right)$, potential available amount of total phenol $\left(A_{\text {Phenol }}\right)$ and AsA $\left(A_{\mathrm{AsA}}\right)$ with the lowest in $L$. chinense in comparison with other species (Table 6 ). $\mathrm{E}-\mathrm{O}_{3}$ had a significant effect on $A_{\mathrm{TAC}}$ but no effect on $A_{\text {Phenol }}$ and $A_{\text {AsA. }}$. A significant interaction between $\mathrm{O}_{3}$ and species was found in $A_{\text {TAC }}$ and $A_{\text {Phenol. }}$. Relative to $\mathrm{CF}, \mathrm{E}-\mathrm{O}_{3}$ significantly decreased $A_{\mathrm{TAC}}$ by $33 \%$ in L. formosana, but increased $A_{\mathrm{TAC}}$ by $60 \%$ in C. glauca. $\mathrm{E}-\mathrm{O}_{3}$ significantly decreased $A_{\text {Phenol }}$ in $C$. camphora by $28 \%$, but increased $A_{\text {Phenol }}$ in Photinia $\times$ fraseri by $26 \%$. On the other hand, $A_{\mathrm{AsA}}$ in all species was not affected significantly by $\mathrm{E}^{-} \mathrm{O}_{3}$, although a large increase (42\%) was found in L. chinense.

\subsection{Correlations between variables}

The AOT40_injury showed a significant negative correlation with the degree of reduction in total biomass, root biomass, $A_{\text {sat }}$ and total chlorophyll content (Fig. 1). As shown in Table 7, SLM in CF plants was positively correlated with AOT40_injury, and negatively correlated with $\mathrm{E}_{-} \mathrm{O}_{3}$-induced reductions in total biomass and $A_{\text {sat }}$. In contrast, $g_{s}$ or antioxidant level (TAC, t-AsA and t-phenols) in CF plants measured at the end of fumigation was not found to be significantly correlated with the AOT40_injury, reduction in total biomass and $A_{\text {sat }}$ (Table 7). However, there was significant or slightly significant $(P<0.06)$ correlation between both AOT40_injury and biomass reduction and potential antioxidant availability or potential amount of antioxidants ( $A_{\text {TAC }}$ or $A_{\text {phenols }}$ ) measured at the end of fumigation in CF plants.

\section{Discussion}

In this study, impacts of $\mathrm{O}_{3}$ on subtropical evergreen and deciduous broadleaved tree species were compared under the

Table 4

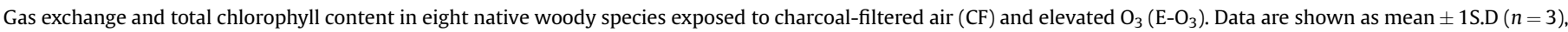
and percentage change in each variable was calculated as $\left(\mathrm{O}_{3}-\mathrm{CF}\right)^{*} 100 / \mathrm{CF}$. ${ }^{*}$, ** indicated significant difference between $\mathrm{CF}$ and $\mathrm{E}-\mathrm{O}_{3}$ at $P \leq 0.05$ and $P \leq 0.01$, respectively.

\begin{tabular}{|c|c|c|c|c|c|c|c|c|c|c|c|c|}
\hline & \multicolumn{3}{|c|}{$A_{\text {sat }}\left(\mu \mathrm{mol} \mathrm{CO} 2 \mathrm{~m}^{-2} \mathrm{~s}^{-1}\right)$} & \multicolumn{3}{|c|}{ 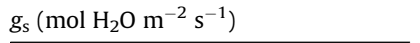 } & \multicolumn{3}{|c|}{$C_{\mathrm{i}}\left(\mu \mathrm{mol} \mathrm{mol}{ }^{-1}\right)$} & \multicolumn{3}{|c|}{ Total chlorophyll (mg/g FM) } \\
\hline & $\mathrm{CF}$ & $\mathrm{E}-\mathrm{O}_{3}$ & $\%$ & $\mathrm{CF}$ & $\mathrm{E}-\mathrm{O}_{3}$ & $\%$ & $\mathrm{CF}$ & $\mathrm{E}-\mathrm{O}_{3}$ & $\%$ & $\mathrm{CF}$ & $\mathrm{E}-\mathrm{O}_{3}$ & $\%$ \\
\hline Liriodendron chinense & $7.65 \pm 1.56$ & $4.47 \pm 1.07$ & $-42^{*}$ & $0.102 \pm 0.020$ & $0.076 \pm 0.026$ & -25 & $235 \pm 12$ & $252 \pm 19$ & 7 & $1.93 \pm 0.17$ & $1.19 \pm 0.26$ & $-39 *$ \\
\hline Liquidambar formosana & $5.54 \pm 0.84$ & $3.53 \pm 0.24$ & $-36^{*}$ & $0.068 \pm 0.012$ & $0.078 \pm 0.004$ & 15 & $231 \pm 14$ & $288 \pm 12$ & $24^{* *}$ & $1.20 \pm 0.11$ & $0.63 \pm 0.11$ & $-48^{* *}$ \\
\hline Cinnamomum camphora & $4.44 \pm 0.91$ & $3.26 \pm 0.19$ & -27 & $0.064 \pm 0.004$ & $0.067 \pm 0.009$ & 6 & $258 \pm 14$ & $294 \pm 2$ & $14^{*}$ & $0.75 \pm 0.08$ & $0.57 \pm 0.06$ & $-25^{*}$ \\
\hline Cyclobalanopsis glauca & $5.87 \pm 0.80$ & $4.18 \pm 0.31$ & $-29 *$ & $0.072 \pm 0.006$ & $0.058 \pm 0.006$ & $-19^{*}$ & $224 \pm 9$ & $244 \pm 20$ & 9 & $3.11 \pm 0.09$ & $3.02 \pm 0.12$ & -3 \\
\hline Schima superba & $6.40 \pm 0.64$ & $4.32 \pm 1.38$ & -32 & $0.063 \pm 0.005$ & $0.071 \pm 0.014$ & 14 & $226 \pm 15$ & $236 \pm 15$ & 5 & $3.02 \pm 0.23$ & $3.01 \pm 0.23$ & 0 \\
\hline Ilex integra & $5.86 \pm 0.28$ & $5.66 \pm 1.30$ & -3 & $0.066 \pm 0.011$ & $0.076 \pm 0.033$ & 15 & $224 \pm 22$ & $228 \pm 45$ & 2 & $2.89 \pm 0.11$ & $2.64 \pm 0.08$ & $-9^{*}$ \\
\hline Photinia $\times$ fraseri & $6.58 \pm 0.21$ & $6.17 \pm 1.15$ & -6 & $0.083 \pm 0.004$ & $0.084 \pm 0.014$ & 1 & $238 \pm 9$ & $240 \pm 11$ & 1 & $2.85 \pm 0.14$ & $2.78 \pm 0.07$ & -2 \\
\hline Neolitsea sericea & $6.49 \pm 0.28$ & $5.47 \pm 1.05$ & -16 & $0.086 \pm 0.011$ & $0.076 \pm 0.014$ & -12 & $232 \pm 12$ & $237 \pm 8$ & 2 & $2.92 \pm 0.11$ & $2.92 \pm 0.10$ & 0 \\
\hline Overall mean $(+/-)$ & & -24 & & & -1 & & & 8 & & & -16 & \\
\hline \multicolumn{13}{|l|}{ ANOVA (P-values) } \\
\hline $\mathrm{O}_{3}$ & & $<0.001$ & & & 0.573 & & & $<0.001$ & & & $<0.001$ & \\
\hline Species & & $<0.001$ & & & 0.013 & & & 0.001 & & & $<0.001$ & \\
\hline $\mathrm{O}_{3} *$ Species & & 0.128 & & & 0.135 & & & 0.135 & & & $<0.001$ & \\
\hline
\end{tabular}


Table 5

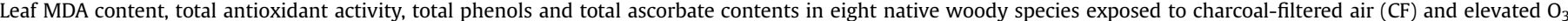

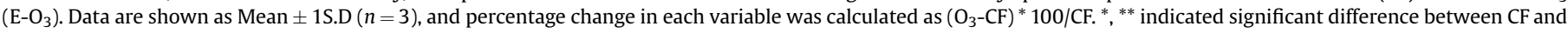
E- $\mathrm{O}_{3}$ at $P \leq 0.05$ and $P \leq 0.01$, respectively.

\begin{tabular}{|c|c|c|c|c|c|c|c|c|c|c|c|c|}
\hline & \multicolumn{3}{|c|}{ MDA content $\left(\mathrm{nmolg}^{-1} \mathrm{FM}\right)$} & \multicolumn{3}{|c|}{$\begin{array}{l}\text { Total antioxidant capacity } \\
\left(\mu \mathrm{molFe}^{2+} \mathrm{g}^{-1} \mathrm{FM}\right)\end{array}$} & \multicolumn{3}{|c|}{$\begin{array}{l}\text { Total phenols (mg gallic acid } \\
\text { equivalents } \mathrm{g}^{-1} \mathrm{FM} \text { ) }\end{array}$} & \multicolumn{3}{|c|}{ Total ascorbate $\left(\mu \mathrm{mol} \cdot \mathrm{g}^{-1} \mathrm{FM}\right)$} \\
\hline & $\mathrm{CF}$ & $\mathrm{E}-\mathrm{O}_{3}$ & $\%$ & $\mathrm{CF}$ & $\mathrm{E}-\mathrm{O}_{3}$ & $\%$ & $\mathrm{CF}$ & $\mathrm{E}-\mathrm{O}_{3}$ & $\%$ & $\mathrm{CF}$ & $\mathrm{E}-\mathrm{O}_{3}$ & $\%$ \\
\hline Liriodendron chinense & $75.9 \pm 2.8$ & $95.0 \pm 1.6$ & $25^{* *}$ & $20.9 \pm 1.2$ & $14.1 \pm 3.2$ & $-33^{*}$ & $7.6 \pm 1.3$ & $9.5 \pm 0.7$ & 25 & $9.4 \pm 1.1$ & $9.9 \pm 0.6$ & 6 \\
\hline Liquidambar formosana & $77.3 \pm 13.7$ & $128.6 \pm 10.3$ & $66^{* *}$ & $28.1 \pm 1.3$ & $20.3 \pm 4.9$ & $-28^{*}$ & $13.1 \pm 2.6$ & $13.5 \pm 0.7$ & 3 & $24.9 \pm 1.9$ & $30.7 \pm 3.1$ & 23 \\
\hline Cinnamomum camphora & $123.2 \pm 9.2$ & $156.8 \pm 10.1$ & $27^{*}$ & $24.8 \pm 7.2$ & $18.4 \pm 1.2$ & -26 & $12.4 \pm 0.7$ & $10.8 \pm 2.4$ & -13 & $14.6 \pm 1.2$ & $16.6 \pm 3.9$ & 14 \\
\hline Cyclobalanopsis glauca & $94.9 \pm 17.6$ & $128.7 \pm 14.5$ & 36 & $20.6 \pm 1.6$ & $27.3 \pm 3.6$ & $32^{*}$ & $12.5 \pm 1.0$ & $9.8 \pm 1.3$ & -21 & $13.9 \pm 2.7$ & $14.7 \pm 1.5$ & 5 \\
\hline Schima superba & $90.9 \pm 2.8$ & $103.9 \pm 6.8$ & $14^{*}$ & $32.7 \pm 5.9$ & $26.5 \pm 4.1$ & -19 & $9.0 \pm 1.4$ & $11.1 \pm 2.3$ & 22 & $20.5 \pm 1.3$ & $23.4 \pm 0.4$ & $14^{*}$ \\
\hline Ilex integra & $35.0 \pm 9.0$ & $43.2 \pm 10.2$ & 23 & $15.2 \pm 3.1$ & $13.0 \pm 1.2$ & -15 & $7.3 \pm 0.5$ & $5.2 \pm 1.3$ & -28 & $5.2 \pm 1.3$ & $4.9 \pm 1.6$ & -7 \\
\hline Photinia $\times$ fraseri & $87.2 \pm 11.3$ & $110.6 \pm 6.5$ & $27^{*}$ & $29.2 \pm 0.7$ & $26.5 \pm 2.1$ & -9 & $10.9 \pm 0.6$ & $13.1 \pm 1.3$ & 21 & $10.5 \pm 0.6$ & $10.7 \pm 0.8$ & 1 \\
\hline Neolitsea sericea & $85.1 \pm 14.0$ & $86.0 \pm 7.1$ & 1 & $20.7 \pm 3.1$ & $19.5 \pm 2.4$ & -6 & $10.5 \pm 3.0$ & $8.8 \pm 1.5$ & -16 & $22.4 \pm 5.1$ & $19.1 \pm 4.0$ & -15 \\
\hline Overall mean $(+\mid-)$ & & 28 & & & -13 & & & -1 & & & 5 & \\
\hline \multicolumn{13}{|l|}{ ANOVA (P-values) } \\
\hline $\mathrm{O}_{3}$ & & $<0.001$ & & & 0.001 & & & 0.688 & & & 0.300 & \\
\hline Species & & $<0.001$ & & & $<0.001$ & & & $<0.001$ & & & $<0.001$ & \\
\hline $\mathrm{O}_{3} *$ Species & & 0.004 & & & 0.007 & & & 0.040 & & & 0.474 & \\
\hline
\end{tabular}

same growth and exposure conditions, and most tree species were investigated for the very first time in the literature. Significant $\mathrm{O}_{3} \times$ species interaction was found in most variables, thereby indicating that the responses to $\mathrm{E}^{-} \mathrm{O}_{3}$ were variable among species.

\subsection{Effects of $\mathrm{E}-\mathrm{O}_{3}$ differed among species}

In this study, $\mathrm{E}^{-\mathrm{O}_{3}}$ (AOT40 of $38.2 \mathrm{ppm} \mathrm{h}$ ) induced visible foliar injuries in all species except Photinia $\times$ fraseri and $N$. sericea, but the symptoms were species-specific. However, the AOT40_injury differed significantly among species, as shown by lower AOT40_injury in two deciduous species compared to those in evergreen species. For deciduous species $L$. chinense and $L$. formosana, the visible injury was first observed at AOT40 of about $10 \mathrm{ppm} \mathrm{h}$, indicating that they were less sensitive than beech and birch seedlings (with a critical AOT40 of $5 \mathrm{ppm} \mathrm{h}$ ) (UNECE, 2004), but more sensitive than oak (with an AOT40 of $18 \mathrm{ppm} \mathrm{h}$ ) (Karlsson et al., 2004). In contrast, most evergreen species except $C$. camphora did not display visible injury until the AOT40 reached above $27 \mathrm{ppm} \mathrm{h}$, indicating that the investigated deciduous species in this study were more sensitive to $\mathrm{O}_{3}$ than the evergreen species.

From the response of biomass to $\mathrm{E}-\mathrm{O}_{3}$, only two deciduous species and $C$. camphora in $\mathrm{E}^{-\mathrm{O}_{3}}$ showed significant reductions (13 26\%) compared to CF plants, whereas most evergreen species showed little change (Table 3). During our experiment, there were three typhoons with a 6-day rain period from 21 August to 26 August, an 8-day rain period from 31 August to 7 September and a 9-day rain period from 9 September to 17 September (Zhang et al., 2011 ), which could have aided the trees's recovery from $\mathrm{O}_{3}$ damage. Heath (2004) indicated that the longer the time between ozone episodes, the greater the ability of the plant to maintain normal growth and development. Hence, it can be inferred that the climate in subtropical regions curtails the negative effects of $\mathrm{O}_{3}$ on most tree species due to possible recovery to some degree during long stretches of rainy days.

From Fig. 1, there was a significantly negative relationship between AOT40_injury and the percentage reduction in both total biomass and root biomass across all eight species, indicating that the species which first showed visible foliar symptoms also had the largest reductions in biomass. Furthermore, the AOT40_injury was significantly negatively correlated with losses in $A_{\text {sat }}$ or total chlorophyll content. All of this suggests that the AOT40 value for the occurrence of initial foliar symptoms can be used as a valuable criterion to rank the sensitivity of these broadleaf species to $\mathrm{O}_{3}$. Similar results were also reported in VanderHeyden et al. (2001) who investigated the visible $\mathrm{O}_{3}$ injury in 16 forest species and found that the species which show the earliest foliar injury were also the most sensitive to $\mathrm{O}_{3}$ throughout the growing season. There was an exception, however, in that some species like maple (Acer campestre) showed symptoms at first but were not clearly the

Table 6

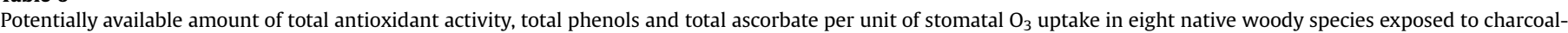

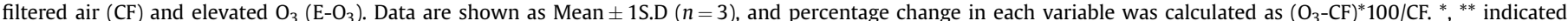
significant difference between $\mathrm{CF}$ and $\mathrm{E}-\mathrm{O}_{3}$ at $P \leq 0.05$ and $P \leq 0.01$, respectively.

\begin{tabular}{|c|c|c|c|c|c|c|c|c|c|}
\hline & \multicolumn{3}{|c|}{$\begin{array}{l}\text { Potential total antioxidant capacity } \\
\left(\mathrm{mmol} \mathrm{Fe}^{2+} \mathrm{nmol}^{-1} \mathrm{~s} \mathrm{O}_{3}^{-1}\right)\end{array}$} & \multicolumn{3}{|c|}{$\begin{array}{l}\text { Potential total phenols } \\
\text { (g gallic acid equivalents } \mathrm{nmol}^{-1} \mathrm{~s}_{3}^{-1} \text { ) }\end{array}$} & \multicolumn{3}{|c|}{$\begin{array}{l}\text { Potential total ascorbate } \\
\left(\mathrm{mmol} \mathrm{ASC} \mathrm{nmol}^{-1} \mathrm{~S} \mathrm{O}_{3}^{-1}\right)\end{array}$} \\
\hline & $\mathrm{CF}$ & $\mathrm{E}-\mathrm{O}_{3}$ & $\%$ & $\mathrm{CF}$ & $\mathrm{E}-\mathrm{O}_{3}$ & $\%$ & $\mathrm{CF}$ & $\mathrm{E}-\mathrm{O}_{3}$ & $\%$ \\
\hline Liriodendron chinense & $0.30 \pm 0.06$ & $0.27 \pm 0.08$ & -11 & $0.11 \pm 0.02$ & $0.19 \pm 0.06$ & 70 & $0.14 \pm 0.02$ & $0.19 \pm 0.05$ & 42 \\
\hline Liquidambar formosana & $1.18 \pm 0.17$ & $0.59 \pm 0.15$ & $-50^{*}$ & $0.55 \pm 0.12$ & $0.39 \pm 0.05$ & -29 & $1.05 \pm 0.23$ & $0.88 \pm 0.12$ & -16 \\
\hline Cinnamomum camphora & $1.30 \pm 0.30$ & $0.83 \pm 0.16$ & -36 & $0.66 \pm 0.03$ & $0.47 \pm 0.04$ & $-28^{* *}$ & $0.77 \pm 0.09$ & $0.76 \pm 0.28$ & -2 \\
\hline Cyclobalanopsis glauca & $1.48 \pm 0.20$ & $2.36 \pm 0.02$ & $60^{*}$ & $0.90 \pm 0.18$ & $0.85 \pm 0.12$ & -5 & $1.00 \pm 0.26$ & $1.27 \pm 0.14$ & 27 \\
\hline Schima superba & $2.04 \pm 0.48$ & $1.33 \pm 0.41$ & -35 & $0.57 \pm 0.14$ & $0.54 \pm 0.12$ & -5 & $1.27 \pm 0.14$ & $1.15 \pm 0.19$ & -10 \\
\hline Ilex integra & $1.42 \pm 0.37$ & $1.22 \pm 0.60$ & -14 & $0.69 \pm 0.12$ & $0.46 \pm 0.17$ & -33 & $0.50 \pm 0.17$ & $0.46 \pm 0.24$ & -7 \\
\hline Photinia $\times$ fraseri & $2.28 \pm 0.25$ & $2.18 \pm 0.41$ & -5 & $0.85 \pm 0.07$ & $1.06 \pm 0.10$ & $26^{*}$ & $0.82 \pm 0.10$ & $0.88 \pm 0.22$ & 7 \\
\hline Neolitsea sericea & $1.25 \pm 0.37$ & $1.28 \pm 0.44$ & 2 & $0.61 \pm 0.11$ & $0.57 \pm 0.16$ & -7 & $1.31 \pm 0.14$ & $1.22 \pm 0.26$ & -7 \\
\hline Overall mean $(+\mid-)$ & & -11 & & & -1 & & & 4 & \\
\hline \multicolumn{10}{|l|}{ ANOVA (P-values) } \\
\hline $\mathrm{O}_{3}$ & & 0.043 & & & 0.139 & & & 0.892 & \\
\hline Species & & $<0.001$ & & & $<0.001$ & & & $<0.001$ & \\
\hline $\mathrm{O}_{3} *$ Species & & 0.009 & & & 0.034 & & & 0.535 & \\
\hline
\end{tabular}




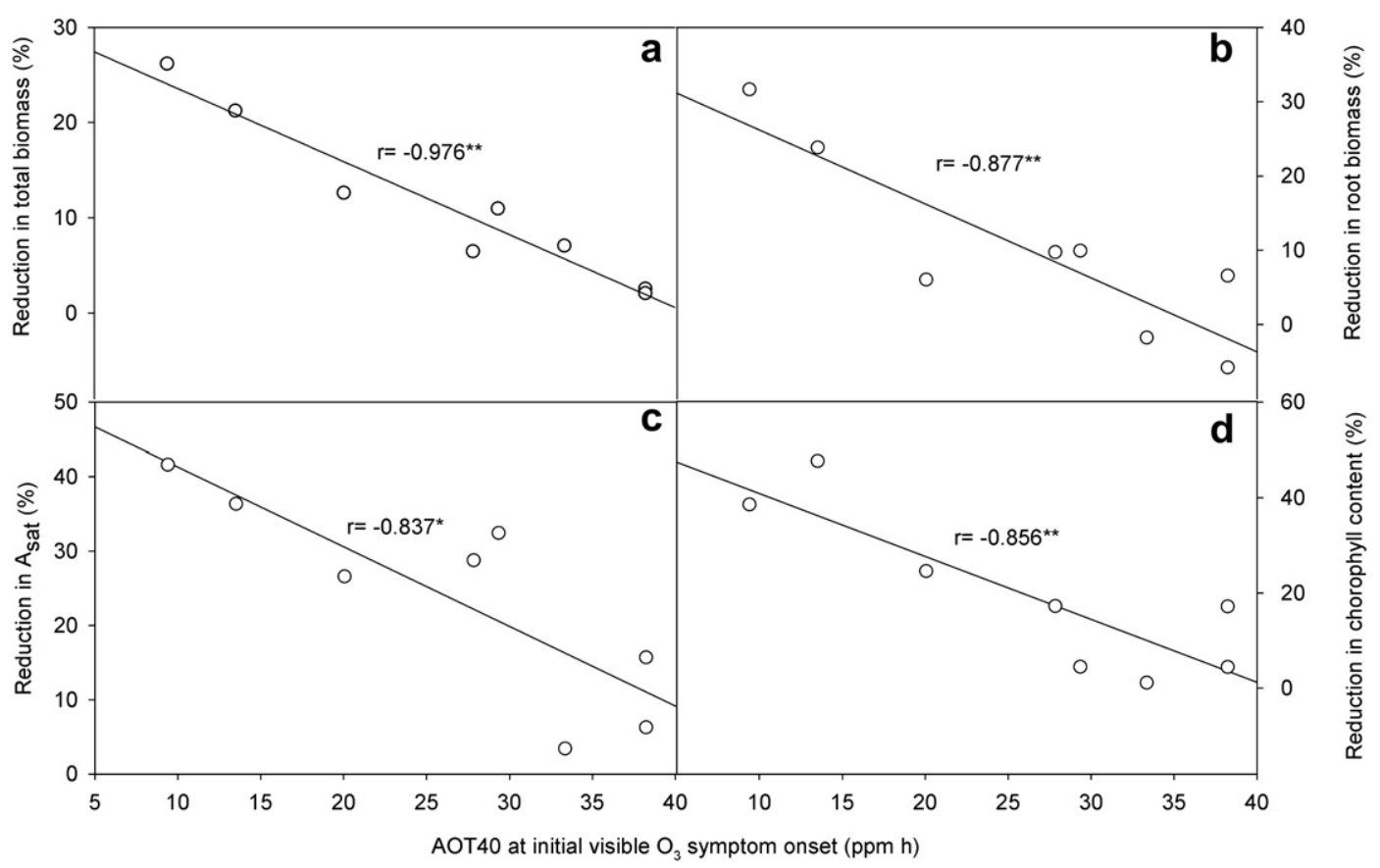

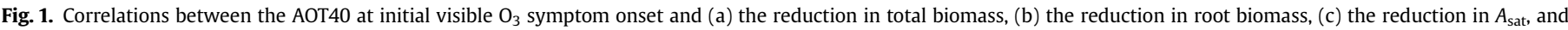
(d) the reduction in total chlorophyll content expressed as $\left(\mathrm{CF}-\mathrm{O}_{3}\right)^{*} 100 / \mathrm{CF}(n=8)$.

most greatly injured by the end of $\mathrm{O}_{3}$ exposure (Calatayud et al., 2007). The present study indicated that the two investigated deciduous species were more sensitive to $\mathrm{O}_{3}$ than most evergreen broadleaf species in terms of both the timing of injury onset and $\mathrm{O}_{3}-$ induced reduction in biomass. Calatayud et al. (2011) compared decidous and evergreen Quercus species in response to $\mathrm{O}_{3}$ and found that decidous Quercus species was more sensitive than evergreen $Q$. ilex based on visible injury, gas exchange, chlorophyll content and biomass responses. Similar results were also found in two deciduous shrubs, which were more sensitive to $\mathrm{O}_{3}$ than two evergreen shrubs (Calatayud et al., 2010).

$\mathrm{O}_{3}$-induced decrease in photosynthesis and premature senescence have been well-documented in many tree species, including deciduous conifer species (e.g. M. glyptostroboides) (Feng et al., 2008), deciduous broadleaf species (e.g. Q. mongolica, F. sylvatica, Quercus pyrenaica) (Calatayud et al., 2011; Matyssek et al., 2010; Yan et al., 2010), evergreen needle species (e.g. Picea abies, Pinus sylvestris) (Emberson et al., 2007; Pretzsch et al., 2010), and evergreen broadleaf species (e.g. C. camphora, Fraxinus ornus) (Feng et al., 2011; Paoletti et al., 2009). In this study, $\mathrm{E}^{-\mathrm{O}_{3}}$ induced

Table 7

Pearson coefficient $(r)$ and levels of significance ( $P$ value) in the correlations between parameters in CF plants at the end of the experiment and the AOT40 at initial $\mathrm{O}_{3}$ symptom onset (AOT40_injury), reduction in total biomass and reduction in $A_{\text {sat }}$, respectively $(n=8)$.

\begin{tabular}{|c|c|c|c|c|c|c|}
\hline & \multicolumn{2}{|c|}{ AOT40_injury } & \multicolumn{2}{|c|}{$\begin{array}{l}\text { Reduction in total } \\
\text { biomass }\end{array}$} & \multicolumn{2}{|c|}{ Reduction in $A_{\text {sat }}$} \\
\hline & $r$ & $P$ & $r$ & $P$ & $r$ & $P$ \\
\hline SLM & 0.922 & 0.001 & -0.922 & 0.001 & -0.914 & 0.002 \\
\hline$g_{s}$ & -0.153 & 0.717 & 0.230 & 0.583 & 0.142 & 0.737 \\
\hline TAC & -0.053 & 0.901 & 0.105 & 0.8305 & 0.294 & 0.480 \\
\hline t-phenols & -0.099 & 0.816 & -0.094 & 0.824 & 0.199 & 0.636 \\
\hline t-AsA & -0.092 & 0.829 & 0.067 & 0.875 & 0.415 & 0.306 \\
\hline$A_{\mathrm{TAC}}$ & 0.724 & 0.042 & -0.702 & 0.052 & -0.549 & 0.159 \\
\hline$A_{\text {phenols }}$ & 0.689 & 0.059 & -0.810 & 0.015 & -0.607 & 0.111 \\
\hline$A_{\mathrm{ASA}}$ & 0.470 & 0.240 & -0.511 & 0.196 & -0.059 & 0.890 \\
\hline
\end{tabular}

a large degree of reduction in $A_{\text {sat }}$ in most plants with an uncoupling of the relationship between $A_{\mathrm{sat}}$ and $g_{\mathrm{s}}$. The response of $g_{\mathrm{s}}$ to $\mathrm{E}-\mathrm{O}_{3}$ was not consistent among species as shown by an increase in some species and a decrease in others. Moreover, $\mathrm{O}_{3}$-induced increase or no change in $C_{\mathrm{i}}$ indicated that the decrease in the photosynthetic capacity in mesophyll cells (Reich, 1987), rather than stomatal closure, appeared to be responsible for the decrease in photosynthetic rate observed in this study.

$\mathrm{E}-\mathrm{O}_{3}$ caused a large reduction in chlorophyll content and TAC, accompanied by a significant increase in MDA content (Tables 4 and 5 ), confirming that there was oxidative stress in most $\mathrm{E}-\mathrm{O}_{3}$ plants. Many studies have reported an increased concentration of antioxidants or elevated defense enzyme activities in response to $\mathrm{O}_{3}$ exposure, which interacts with $\mathrm{O}_{3}$ to neutralize its effect on plant tissues (Löw et al., 2006). Furthermore, the generation and accumulation of superoxide and/or peroxide may differ among species (Wohlgemuth et al., 2002). In this study, however, all plants showed lower total antioxidant capacity in $\mathrm{E}-\mathrm{O}_{3}$ relative to $\mathrm{CF}$ at the end of fumigation, with an exception of $C$. glauca, although $\mathrm{E}-\mathrm{O}_{3}$ caused considerable increases of total phenol content in L. chinense, S. superba and Photinia $\times$ fraseri (Table 5). The results suggested that increased phenol contents, and other possible related antioxidant contents and antioxidant enzymes activities were not enough to detoxify the high concentration of $\mathrm{O}_{3}$ in the $\mathrm{E}-\mathrm{O}_{3}$ treatment.

\subsection{Possible causes for the different sensitivities to $\mathrm{O}_{3}$}

Inherent SLM can distinguish roughly $\mathrm{O}_{3}$-sensitive and $\mathrm{O}_{3}$ tolerant species (Bussotti, 2008). Higher $\mathrm{O}_{3}$-tolerant species had a lower SLA i.e. higher SLM (Calatayud et al., 2011; Franzaring et al., 2000), which can be a consequence of a high density of mesophyll tissues or of great leaf thickness (Bussotti, 2008; Wieser et al., 2002). Thick leaves with a palisade mesophyll have a greater quantity of chlorophyll molecular per unit of leaf surface, thus enhancing the photosynthesis capacity of this species, which is capable of feeding its detoxification processes more intensely (Bussotti et al., 2007). From Table 7, SLM in CF had a significant 
positive correlation with AOT40_injury and a significant negative relationship with the loss in biomass and net photosynthesis, indicating that $\mathrm{O}_{3}$ sensitivity is likely to be higher for species with an inherently lower SLM. Thus, it can be inferred that inherent SLM may be one key parameter to determine the onset of visible injury and plant sensitivity to $\mathrm{O}_{3}$. Similar results were also found in different clones of silver birch, where the thickness of leaves was an important factor influencing the development of foliar visible $\mathrm{O}_{3}$ injury (Karlsson et al., 2007).

The harmful effects of $\mathrm{O}_{3}$ on plants directly depend on the stomatal $\mathrm{O}_{3}$ flux (Gerosa et al., 2009), largely controlled by the degree of stomatal opening (Castagna and Ranieri, 2009). Zhang et al. (2001) reported that species with intrinsically higher $g_{s}$ have a higher potential $\mathrm{O}_{3}$ uptake and thus exhibit a greater negative growth response to a given level of $\mathrm{O}_{3}$ than species with lower $g_{s}$. During the experiment, the $g_{s}$ in each species was measured three times in total, and there was no significant interaction of dates $\times$ species $\times \mathrm{O}_{3} \quad(P=0.829)$, suggesting that the response of each species to $\mathrm{E}-\mathrm{O}_{3}$ was similar at different measurement dates. Therefore, the $g_{s}$ measured at the last time was used to make regression relationships with other parameters. From the analysis, higher $g_{s}$ only partially explained the earlier occurrence of visible symptom and greater reduction in $A_{\text {sat }}$ in one deciduous tree $L$. chinense. However, the other five broadleaved evergreen species, with intrinsically higher $g_{s}$, showed larger AOT40_injury and lower losses in biomass, suggesting that $g_{s}$ did not contribute to the different sensitivity to $\mathrm{O}_{3}$ among selected species (Table 7). Similar findings were reported in inter- or intraspecific differences in $\mathrm{O}_{3}$ sensitivity for aspen and Mediterranean shrubs (Calatayud et al., 2010; Nikula et al., 2009).

It can be inferred that the negative effects of $\mathrm{O}_{3}$ on plants were dependent not only on the $\mathrm{O}_{3}$ flux (Matyssek et al., 2007), but on the balance between the flux and detoxification to cope with oxidative stress (Castagna and Ranieri, 2009). The antioxidant capacity per unit of $\mathrm{O}_{3}$ influx was assumed to be the best indicator to combine these two factors. From our results, both AOT40_injury and $\mathrm{O}_{3}$-induced reduction in total biomass were strongly related with $A_{\text {TAC }}$ or $A_{\text {Phenols, }}$ but not with TAC or phenol or AsA content, indicating that potential detoxification capacity, rather than antioxidant capacity, contributed to the different response to $\mathrm{O}_{3}$ among the eight subtropical broadleaved species. Similar results were also found in Di Baccio et al. (2008), in which lower potential detoxification capacity in the poplar clone Eridano contributed to the greater sensitivity to $\mathrm{O}_{3}$ than clone I-214, although foliar antioxidant defense capacities were increased in the clone Eridano. The present results further confirmed that the effective $\mathrm{O}_{3}$ flux (i.e., the balance between the flux and detoxification in plants) was more important for assessing the sensitivity of species to $\mathrm{O}_{3}$ than $g_{\mathrm{s}}$ or antioxidant (Musselman et al., 2006). Admittedly, $g_{s}$ or antioxidant capacity evaluated by the activity of radical scavenging enzymes and concentration of antioxidants changes with time during the $\mathrm{O}_{3}$ fumigation. The analysis above based on the biochemical measurements at the end of the fumigation was able to provide some clues to determine the biochemical mechanisms of sensitivity of plants to $\mathrm{O}_{3}$.

Notably, $N$. sericea had similar SLM, $g_{\text {s }}$ and intrinsic antioxidant capacity to $\mathrm{C}$. glauca, but showed a totally different $\mathrm{O}_{3}$ sensitivity. Compared with the $\mathrm{CF}$ treatment, $\mathrm{E}_{-} \mathrm{O}_{3}$ had no overall effects on carbon assimilation rate and biomass accumulation in $N$. sericea. The resistance of $N$. sericea could be related to its leaf morphology, e.g. golden densely fine hair, on both surfaces of young leaves or some anatomy features. Hayes et al. (2007) investigated the sensitivity of 83 semi-natural vegetation species to $\mathrm{O}_{3}$ and found that plants of the therophyte lifeform were particularly sensitive to $\mathrm{O}_{3}$ and that species with higher mature leaf $\mathrm{N}$ concentration were more sensitive to $\mathrm{O}_{3}$ than those with lower leaf $\mathrm{N}$ concentration. It was suggested that other plants factors like leaf longevity, foliar $\mathrm{N}$ concentration and BVOC (especially ethylene) emission rate are also necessary to further identify the response of species to $\mathrm{O}_{3}$.

The $\mathrm{O}_{3}$ concentration used in this study was much higher than the mean daytime $\mathrm{O}_{3}$ concentration in the surrounding regions, but it is similar to the 1-h peak concentration (Wang et al., 2006). However, the purpose of this study was to determine the $\mathrm{O}_{3}$ sensitivity among eight woody species; hence, the simplest way is that small seedlings were exposed to high $\mathrm{O}_{3}$ concentration for a relatively short term until almost all species showed visible injury. Admittedly, the conclusions obtained in this study remain to be verified in other experiments due to some uncertainties. The seedlings were grown in pots with ample water and nutrients, and therefore had more dynamic carbon economies than mature trees which are less allocationally plastic and must compete for light, water, and other resources (Ollinger et al., 1997). Moreover, the degree of increase or decrease in the gas exchange and antioxidant capacity varied significantly from day to day and from one season to another, suggesting that a multi-year experiment with many measurements of plant structure and functions related to the sensitivity to $\mathrm{O}_{3}$ and data analysis based on the accumulated stomatal $\mathrm{O}_{3}$ uptake is needed to clarify the effects of $\mathrm{O}_{3}$ on Chinese tree species, the difference in the sensitivity of tree species to $\mathrm{O}_{3}$ and its mechanisms.

\section{Conclusions}

After exposure to $\mathrm{E}_{-} \mathrm{O}_{3}$ for one growing season, visible injury and significant reduction in carbon assimilation and biomass accumulation were found in some native subtropical broadleaved woody species in Eastern China. The species which first showed visible foliar symptoms also had the largest reductions in biomass. The evergreen broadleaf species that were investigated showed less sensitivity to $\mathrm{O}_{3}$ than the two deciduous species in terms of AOT40 value at initial visible $\mathrm{O}_{3}$ injury onset and biomass losses. From the variables investigated, specific leaf mass, rather than $g_{s}$, contributed significantly to the different ozone sensitivity between eight broadleaf species. Notably, foliar morphology (e.g. densely fine hair) could not be neglected as possible reasons to explain $\mathrm{O}_{3}$ tolerance. It remains to be verified whether the observed responses to $\mathrm{O}_{3}$ in these species changes with the extended experimental seasons or in natural forest ecosystems.

\section{Acknowledgements}

This research was supported by the National Natural Science Foundation of China (No. 30700086, 31170424) and Tiantong National Station of Forest Ecosystem of China (No. TT200707). We gratefully acknowledge Dr. Xihua Wang, Ms. Fangfang Yao and Dr. Yuan Tian for offering the location and ozone Monitor, respectively. We also acknowledge Mr. Wenzhi Song for his technical support in the open-top chambers system. Special appreciation is given to Professor Zongwei Feng for his constructive suggestions on the experimental design. We also express our appreciation to Dr. Charles Chen for English improvement throughout the manuscript.

\section{References}

Augustaitis, A., Bytnerowicz, A., 2008. Contribution of ambient ozone to Scots pine defoliation and reduced growth in the Central European forests: a Lithuanian case study. Environmental Pollution 155, 436-445.

Benzie, I.F.F., Strain, J.J., 1999. Ferric reducing/antioxidant power assay: direct measure of total antioxidant activity of biological fluids and modified version 
for simultaneous measurement of total antioxidant power and ascorbic acid concentration. Methods in Enzymology 299, 15-27.

Bussotti, F., 2008. Functional leaf traits, plant communities and acclimation processes in relation to oxidative stress in trees: a critical overview. Global Change Biology 14, 2727-2739.

Bussotti, F., Desotgiu, R., Cascio, C., Strasser, R.J., Gerosa, G., Marzuoli, R., 2007. Photosynthesis responses to ozone in young trees of three species with different sensitivities, in a 2-year open-top chamber experiment (Curno, Italy). Physiologia Plantarum 130, 122-135.

Bytnerowicz, A., Omasa, K., Paoletti, E., 2007. Integrated effects of air pollution and climate change on forests: a northern hemisphere perspective. Environmental Pollution 147, 438-445.

Calatayud, V., Cerveró, J., Calvo, E., García-Breijo, F.J., Reig-Armiñana, J., Sanz, M.J., 2011. Responses of evergreen and deciduous Quercus species to enhanced ozone levels. Environmental Pollution 159, 55-63.

Calatayud, V., Cerveró, J., Sanz, M.J., 2007. Foliar, physiologial and growth responses of four maple species exposed to ozone. Water, Air, and Soil Pollution 185 239-254.

Calatayud, V., Marco, F., Cerveró, J., Sánchez-Peña, G., Sanz, M.J., 2010. Contrasting ozone sensitivity in related evergreen and deciduous shrubs. Environmental Pollution 158, 3580-3587.

Castagna, A., Ranieri, A., 2009. Detoxification and repair process of ozone injury: from $\mathrm{O}_{3}$ uptake to gene expression adjustment. Environmental Pollution 157, 1461-1469.

D'HaeseVandermeiren, K., Asard, H., Horemans, N., 2005. Other factors than apoplastic ascorbate contribute to the differential ozone tolerance of two clones of Trifolium repens L. Plant, Cell and Environment 28, 623-632.

Di Baccio, D., Castagna, A., Paoletti, E., Sebastiani, L., Ranieri, A., 2008. Could the differences in $\mathrm{O}_{3}$ sensitivity between two poplar clones be related to a difference in antioxidant defense and secondary metabolic response to $\mathrm{O}_{3}$ influx? Tree Physiology 28, 1761-1772.

Emberson, L.D., Buker, P., Ashmore, M.R., 2007. Assessing the risk caused by ground level ozone to European forest trees: a case study in pine, beech and oak across different climate regions. Environmental Pollution 147, 454-466.

Feng, Z.Z., Niu, J.F., Zhang, W.W., Wang, X.K., Yao, F.F., Tian, Y., 2011. Effects of ozone exposure on sub-tropical evergreen Cinnamomum camphora seedlings grown in different nitrogen loads. Trees - Structure and Function 25, 617-625.

Feng, Z.Z., Zeng, H.Q., Wang, X.K., Zheng, Q.W., Feng, Z.W., 2008. Sensitivity of Metasequoia glyptostroboides to ozone stress. Photosynthetica 46, 463-465.

Franzaring, J., Tonneijck, A.E.G., Kooijman, A.W.N., Dueck, Th.A., 2000. Growth responses to ozone in plant species from wetlands. Environmental and Experimental Botany 44, 39-48.

Gerosa, G., Marzuoli, R., Desotgiu, R., Bussotti, F., Ballarin-Denti, A., 2008. Visible leaf injury in young trees of Fagus sylvatica L. and Ouercus robur L. in relation to ozone uptake and ozone exposure. An Open-Top Chambers experiment in South Alpine environmental conditions. Environmental Pollution 152, 274-284.

Gerosa, G., Marzuoli, R., Desotgiu, R., Bussotti, F., Ballarin-Denti, A., 2009. Validation of the stomatal flux approach for the assessment of ozone visible injury in young forest trees. Results from the TOP (transboundary ozone pollution) experiment at Curno, Italy. Environmental Pollution 157, 1497-1505.

Gillespie, K.M., Ainsworth, E.A., 2007. Measurement of reduced, oxidized and total ascorbate content in plants. Nature Protocols 2, 871-874.

Haberer, K., Herbinger, K., Alexou, M., Tausz, M., Rennenberg, H., 2007. Antioxidative defence of old growth beech (Fagus sylvatica) under double ambient $\mathrm{O}_{3}$ concentrations in a free-air exposure system. Plant Biology 9, 215-226.

Hayes, F., Jones, M.L.M., Mills, G., Ashmore, M., 2007. Meta-analysis of the relative sensitivity of semi-natural vegetation species to ozone. Environmental Pollution 146, 754-762.

He, X.Y., Fu, S.L., Chen, W., Zhao, T.H., Xu, S., Tuba, Z., 2007. Changes in effects of ozone exposure on growth, photosynthesis, and respiration of Ginkgo biloba in Shenyang urban area. Photosynthetica 45, 555-561.

Heath, R., 2004. The modification of photosynthetic capacity induced by ozone exposure. Photosynthesis and the Environment 5, 409-433.

Heath, R.L., Packer, L., 1968. Photoperoxidation in isolated chloroplasts: I. Kinetics and stoichiometry of fatty acid peroxidation. Archives of Biochemistry and Biophysics 125, 189-198.

Inclán, R., Gimeno, B.S., Peñuelas, J., Gerant, D., Quejido, A., 2011. Carbon isotope composition, macronutrient concentrations, and carboxylating enzymes in relation to the growth of Pinus halepensis Mill. when subject to ozone stress. Water, Air, and Soil Pollution 214, 587-598.

Kähkönen, M.P., Hopia, A.I., Vuorela, H.J., Rauha, J.P., Pihlaja, K., Kujala, T.S., Heinonen, M., 1999. Antioxidant activity of plant extracts containing phenolic compounds. Journal of Agricultural and Food Chemistry 47, 3954-3962.

Karlsson, P.E., Tang, L., Sundberg, J., Chen, D., Lindskog, A., Pleijel, H., 2007. Increasing risk for negative ozone impacts on vegetation in northern Sweden. Environmental Pollution 150, 96-106.

Karlsson, P.E., Uddling, J., Braun, S., Broadmeadow, M., Elvira, S., Gimeno, B.S., Le Thiec, D., Oksanen, E., Vandermeiren, K., Wilkinson, M., Emberson, L., 2004. New critical levels for ozone effects on young trees based on AOT40 and simulated cumulative leaf uptake of ozone. Atmospheric Environment 38, 2283-2294

Kitao, M., Löw, M., Heerdt, C., Grams, T.E.E., Häberle, K.H., Matyssek, R., 2009. Effects of chronic elevated ozone exposure on gas exchange responses of adult beech trees (Fagus sylvatica) as related to the within-canopy light gradient. Environmental Pollution 157, 537-544.
Kontunen-Soppela, S., Riikonen, J., Ruhanen, H., Brosché, M., Somervuo, P. Peltonen, P., Kangasjärvi, J., Auvinen, P., Paulin, L., Keinänen, M., Oksanen, E., Vapaavuori, E., 2010. Differential gene expression in senescing leaves of two silver birch genotypes in response to elevated $\mathrm{CO}_{2}$ and tropospheric ozone. Plant, Cell and Environment 33, 1016-1028.

Lichtenthaler, H.K., 1987. Chlorophylls and carotenoids: pigments of photosynthetic biomembranes. Methods in Enzymology 148, 350-382.

Löw, M., Herbinger, K., Nunn, A.J., Häberle, K.H., Leuchner, M., Heerdt, C., Werner, H., Wipfler, P., Pretzsch, H., Tausz, M., 2006. Extraordinary drought of 2003 overrules ozone impact on adult beech trees (Fagus sylvatica). Trees - Structure and Function 20, 539-548.

Matyssek, R., Bytnerowicz, A., Karlsson, P.E., Paoletti, E., Sanz, M., Schaub, M. Wieser, G., 2007. Promoting the $\mathrm{O}_{3}$ flux concept for European forest trees. Environmental Pollution 146, 587-607.

Matyssek, R., Wieser, G., Ceulemans, R., Rennenberg, H., Pretzsch, H., Haberer, K. Löw, M., Nunn, A., Werner, H., Wipfler, P., Oßwald, W., Nikolova, P., Hanke, D.E., Kaigher, H., Tausz, M., Bahnweg, G., Kitao, M., Dieler, J., Sandermann, H. Herbinger, K., Grebenc, M., Blumenröther, M., Deckmyn, G., Grams, T.E.E. Heerdt, C., Leuchner, M., Fabian, P., Häberle, K.H., 2010. Enhanced ozone strongly reduces carbon sink strength of adult beech (Fagus sylvatica) - resume from the free-air fumigation study at Kranzberg Forest. Environmental Pollution 158, 2527-2532.

McGrath, J.M., Karnosky, D.F., Ainsworth, E.A., 2010. Spring leaf flush in aspen (Populus tremuloides) clones is altered by long-term growth at elevated carbon dioxide and elevated ozone concentration. Environmental Pollution 158, 1023-1028.

McLaughlin, S.B., Nosal, M., Wullschleger, S.D., Sun, G., 2007. Interactive effects of ozone and climate on tree growth and water use in a southern Appalachian forest in the USA. New Phytologist 174, 109-124.

Musselman, R.C., Lefohn, A.S., Massman, W.J., Heath, R.L., 2006. A critical review and analysis of the use of exposure-and flux-based ozone indices for predicting vegetation effects. Atmospheric Environment 40, 1869-1888.

Nali, C., Paoletti, E., Marabottini, R., Della Rocca, G., Lorenzini, G., Paolacci, A.R. Ciaffi, M., Badiani, M., 2004. Ecophysiological and biochemical strategies of response to ozone in Mediterranean evergreen broadleaf species. Atmospheric Environment 38, 2247-2257.

Nikula, S., Percy, K., Oksanen, E., Holpainen, T., Manninen, S., 2009. Effects of elevated ozone on growth and foliar traits of European and hybrid aspen. Boreal Environment Research 14, 29-47.

Oksanen, E., Riikonen, J., Kaakinen, S., Holopainen, T., Vapaavuori, E., 2005. Structural characteristics and chemical composition of birch (Betula pendula) leaves are modified by increasing $\mathrm{CO}_{2}$ and ozone. Global Change Biology 11, 732-748

Ollinger, S.V., Aber, J.D., Reich, P.B., 1997. Simulating ozone effects on forest productivity: interactions among leaf-, canopy- and stand-level processes. Ecological Applications 7, 1237-1251.

Orendovici-Best, T., Skelly, J.M., Davis, D.D., Ferdinand, J.A., Savag, J.E., Stevenson, R.E., 2008. Ozone uptake (flux) as it relates to ozone-induced foliar symptoms of Prunus serotina and Populus maximowizii $\times$ trichocarpa. Environmental Pollution 151, 79-92.

Paoletti, E., 2006. Impact of ozone on Mediterranean forests: a review. Environmental Pollution 144, 463-474.

Paoletti, E., 2009. Ozone and urban forests in Italy. Environmental Pollution 157, 1506-1512.

Paoletti, E., Contran, N., Bernasconi, P., Günthardt-Goerg, M.S., Vollenweider, P., 2009. Structural and physiological responses to ozone in Manna ash (Fraxinus ornus L.) leaves of seedlings and mature trees under controlled and ambient conditions. Science of the Total Environment 407, 1631-1643.

Paoletti, E., Schaub, M., Matyssek, R., Wieser, G., Augustaitis, A., Bastrup-Birk, A.M. Bytnerowicz, A., Günthardt-Goerg, M.S., Müller-Starck, G., Serengil, Y., 2010 Advances of air pollution science: from forest decline to multiple-stress effects on forest ecosystem services. Environmental Pollution 158, 1986-1989.

Pina, J.M., Moraes, R.M., 2010. Gas exchange, antioxidants and foliar injuries in saplings of a tropical woody species exposed to ozone. Ecotoxicology and Environmental Safety 73, 685-691.

Pretzsch, H., Dieler, J., Matyssek, R., Wipfler, P., 2010. Tree and stand growth of mature Norway spruce and European beech under long-term ozone fumigation. Environmental Pollution 158, 1061-1070.

Reich, P.B., 1987. Quantifying plant response to ozone: a unifying theory. Tree Physiology 3, 63-91.

Ren, W., Tian, H.Q., Tao, B., Chappelka, A., Sun, G., Lu, C.Q., Liu, M.L., Chen, G.S., Xu, X.F., 2011. Impacts of tropospheric ozone and climate change on net primary productivity and net carbon exchange of China's forest ecosystems. Global Ecology and Biogeography 20, 391-406.

Tausz, M., Grulke, N.E., Wieser, G., 2007. Defense and avoidance of ozone under global change. Environmental Pollution 147, 525-531.

Tkacz, B., Moody, B., Castillo, J.V., Fenn, M.E., 2008. Forest health conditions in North America. Environmental Pollution 155, 409-425.

UNECE, 2004. Manual on Methodologies and Criteria for Modelling and Mapping Critical Loads and Levels and Air Pollution Effects, Risks and Trends. UNECE. http://www.icpmapping.org.

VanderHeyden, D., Skelly, J., Innes, J., Hug, C., Zhang, J., Landolt, W., Bleuler, P., 2001. Ozone exposure thresholds and foliar injury on forest plants in Switzerland. Environmental Pollution 111, 321-331.

Wang, H.X., Zhou, L.J., Tang, X.Y., 2006. Ozone concentrations in rural regions of the Yangtze Delta in China. Journal of Atmospheric Chemistry 54, 255-265. 
Wang, X.K., Manning, W., Feng, Z.W., Zhu, Y.G., 2007. Ground-level ozone in China: distribution and effects on crop yields. Environmental Pollution 147, 394-400.

Wieser, G., Tegischer, K., Tausz, M., Häberle, K.H., Grams, T.E.E., Matyssek, R., 2002. Age effects on Norway spruce (Picea abies) susceptibility to ozone uptake: a novel approach relating stress avoidance to defense. Tree Physiology 22, $583-590$.

Wittig, V.E., Ainsworth, E.A., Naidu, S.L., Karnosky, D.F., Long, S.P., 2009. Quantifying the impact of current and future tropospheric ozone on tree biomass, growth, physiology and biochemistry: a quantitative meta-analysis. Global Change Biology 15, 396-424.

Wohlgemuth, H., Mittelstrass, K., Kschieschan, S., Bender, J., Weigel, H.J. Overmyer, K., Kangasjävi, J., Sandermann, H., Langebartels, C., 2002. Activation of an oxidative burst is a general feature of sensitive plants exposed to the air pollutant ozone. Plant, Cell and Environment 25, 717-726.
Yamaguchi, M., Watanabe, M., Iwasaki, M., Tabe, C., Matsumura, H., Kohno, Y., Izuta, T., 2007. Growth and photosynthetic responses of Fagus crenata seedlings to $\mathrm{O}_{3}$ under different nitrogen loads. Trees - Structure and Function 21, 707-718.

Yan, K., Chen, W., He, X.Y., Zhang, G.Y., Xu, S., Wang, L., 2010. Responses of photosynthesis, lipid peroxidation and antioxidant system in leaves of Quercus mongolica to elevated $\mathrm{O}_{3}$. Environmental and Experimental Botany 69, 198-204.

Zhang, J., Ferdinand, J.A., Vanderheyden, D.J., Skelly, J.M., Innes, J.L., 2001. Variation of gas exchange within native plant species of Switzerland and relationships with ozone injury: an open-top experiment. Environmental Pollution 113, 177-185.

Zhang, W.W., Niu, J.F., Wang, X.K., Tian, Y., Yao, F.F., Feng, Z.Z., 2011. Effects of ozone exposure on growth and photosynthesis of the seedlings of Liriodendron chinense (Hemsl.) Sarg, a native tree species of subtropical China. Photosynthetica $49,29-36$ 